\title{
Auditing Techniques to Avoid Cost Accounting Frauds
}

\section{Vedat Akman}

Beykent University, Turkey | akmanvedat@yahoo.com

\section{Berkan Acar}

Yalova University, Turkey | acarberkan@hotmail.com

\section{Cevdet Kızıl}

Istanbul Medeniyet University, Turkey | cevdetkizil@yahoo.com

Volume 10 No 1 (2020) ｜ ISSN 2158-8708 (online) ｜ＤOI 10.5195/emaj.2020.210 | http://emaj.pitt.edu Abstract

Today, we observe the importance of accuracy of financial statements in every corporation. Accounting scandals have caused important losses both in the macro and micro levels. This issue proves the significance of financial statement accuracy. This accuracy is provided by the trust environment. Therefore, it is necessary to provide the required environment of confidence for financial markets to improve and function effectively against increasing accounting frauds gradually. That can only be possible by using different auditing techniques, running inventory counting such as cash and stock, establishing strong internal controls, managing efficiently and benefiting from technology integrated auditing. The aim of this study is to investigate the most effective auditing techniques to avoid cost accounting frauds. In this research, the most effective auditing techniques for detecting and preventing fraud are investigated by using the case analysis method. Also, the well known scandals related with Olympus, Worldcom, Tesco, Sunbeam and Parmalat companies are examined as a part of the case analysis. Finally, recommendations and suggestions regarding fraud prevention methods are presented.

Keywords: Accounting, Cost Accounting, Auditing, Scandals, Fraud

\section{(c) $)$ EY}

New articles in this journal are licensed under a Creative Commons Attribution 3.0 United States License.

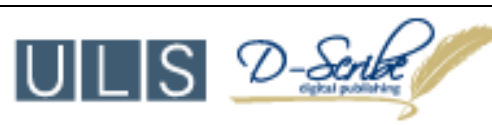

This journal is published by the University Library System of the University of Pittsburgh as part of its D-Scribe Digital Publishing Program, and is cosponsored by the University of Pittsburgh Press. 


\section{Auditing Techniques to Avoid Cost Accounting Frauds}

\section{Vedat Akman \\ Berkan Acar \\ Cevdet Kızıl}

\section{Introduction}

Accounting is a science and art that records, classifies, summarizes, reports and interprets the financial events and transactions expressed in monatary terms and notifies results to interested individuals and institutions (Kızıl and Kızıl, 2007; Öztürk, 2016). Accounting reveals an information system that provides common core for management's success and effective control in all enterprises. It is of great importance to design, establish and implement the accounting system in today's advanced industrial environments (Şakrak, 1997).

Cost accounting is an account and registration system that allows the determination and monitoring of types of costs that make up the cost of manufactured goods or services in terms of their place of origin and type of related product or service. Also, cost accounting is one of the sources, where the information necessary to prepare the budget is provided. The information obtained from cost accounting is not directly used in budgets. However, forward-looking estimates can be made using this information. It is predicted how the expenditures will follow in the future and what the sales volume will be based on the cost data of the past years (Akdoğan, 2014).

Futhermore, cost accounting is an accounting system that analyzes the production cost information required in the main activities of enterprises. This information is used in all parts of the management function from planning to control of production activities. At the same time, cost accounting system is one of the most important factors determining a firm's competitive power. Thus, the best way to determine costs directly relates to firm profitability and the amount of product sales, which provide a direct competitive advantage (Özay, 1992).

Accounting audit is a systematic process that collects and evaluates evidence objectively in order to investigate the extent of compliance with predetermined criteria. In accounting, an auditor is an expert who carries out auditing activities, possesses professional knowledge and experience. Auditors should also act independently and possess high moral qualifications required by the profession. An accounting auditor investigates accuracy of financial statements of business and they aim to provide reliable and accurate information to the financial statement users such as creditors, business executives and prospective investors. Thus, auditing satisfies the need of reliable information for internal and external users. It also increases the reliability of financial statements (Öztürk, 2016).

It is very important that the financial statements related to cost accounting reflect the reality. Information users need to be certified by a third party to increase the credibility of the information contained in the financial statements prepared by the business executives. Therefore, auditing should especially intervene at this point (Güredin, 1999).

Fraud is a significant issue that cannot be ignored in public enterprises and the private sector. Fraud operations inhibit the operating activities and operating efficiency of the corporations. Additionally, it weakens the competitive power of the enterprises and it minimizes the profits as well as services of the companies. Although, the fraud and irregularities have begun very long time ago, it is once again revealed that important measures against fraud and corruption have to be taken. Crises in the United States (U.S.) and Europe, especially the Enron scandal, as well as the financial crises spreading to the world should be mentioned concerning this issue (Kandemir and Kandemir, 2012).

Fraud is not just peculate. It is at the same time an irregularity, unethical behavior and abuse of power. Because of this situation, it is almost impossible to reveal all forms of fraud. The purpose of the audit techniques against fraud and corruption is to take the necessary precautions and to minimize the damages that will be caused (Emir, 2008).

In this study, we focused on auditing techniques towards cost accounting frauds. Thus, we tried to investigate the most effective auditing techniques for detecting fraud. Additionally, we attempted to determine fraud methods that are commonly used in cost accounting and we also aimed to identify appropriate methods for detecting fraud.

\section{Literature Review}

Omair and Alturki's paper (2020) titled "A Systematic Literature Review of Fraud Detection Metrics in Business Processes" emphasized that, fraud is a leading source of corporate losses, amounting up to $5 \%$ of yearly revenues. The research findings showed that, a great portion of research had examined detection metrics for possible fraud, but less attention had been paid to Process-Based Fraud (PBF). Also, the already available PBF detection metrics did not sufficiently address the needs of separate conceptual perspectives on firm processes (Omair and Alturki, 2020).

Aslan and Kizıl's study (2019) titled "Üretim Maliyetlerinin Denetimine Genel Bir Bakış" stressed that, audit is a very important and critical for businesses in today's business world. Because, while auditing prevents asset losses in enterprises, it is also effective in providing efficiency and productivity. At the same time, technological advances observed in recent years have further increased the critical role of auditing. The production costs of businesses can be controlled with the help of auditing (Aslan and Kız1, 2019).

Research by Kızıl et. al. (2019) titled "İktisadi ve Sosyal Yönleriyle İnovasyon" concentrated on the impact of innovation on accounting and auditing professions. It was mentioned that, auditing techniques today were highly integrated with technology. The implemention of modern audit techniques on cost accounting and managerial accounting was dicussed as well (K1zil C. et. al., 2019).

Kızıl and Kaşbaşı (2018) conducted a reseearch about accounting scandals and fraud titled "Accounting 
Scandals and Eye-Catching Frauds: USA-Japan Comparison by Considering the Role of Auditing". The authors underlined the fact that, independent auditing firms do not always fulfill their duties completely. Thus, legislation was introduced in United States of America (U.S.), Europe and Asian countries, including Japan. Public oversight bodies were also set up as well. However, despite the introduced laws, regulations, arrangements and public oversight bodies, the risk of accounting scandals still goes on. This is because laws, regulations, arrangements and introduction of public oversight bodies are delayed and they are not matching the demands of changing market conditions. Accounting scandals and eye-cathing frauds were discussed by making a comparison between the U.S. and Japan, while considering and discussing the role of auditing (K1zil and Kaşbaşı, 2018).

Kızıl and Doğan's study (2017) titled ""Audit Techniques for Protecting against Cyber Attacks: A Bilateral Approach of Case Studies and Interview" discussed issues such as risk based audit, Information Technologies (IT) audit with COBIT, integrated audit, corporate governance, the COSO framework, big data in auditing, cloud technologies, internet of things (IOTs), data fraud and theft, classification of data risks, encryption of data, data analytics and log records, as well as auditing and ethics relationship. These were listed as contemporary issues related to auditing. Plus, it was mentioned that cyber attacks were harming the corporations. Thus, auditing techniques to protect against cyber attacks were presented. This study benefited from case analysis and an interview with a retired IT professional as a bilateral approach for data and methodology (Kızıl and Doğan, 2017).

Aslan, Kizıl and Din's (2017) research titled "Muhasebe Hata ve Hileleri Üzerinde Etkili Faktörlerin Muhasebe Meslek Etiği Kapsamında Analizi: Yalova Örneği" focused on the difference between accounting errors and fraud. Additionally, the negative consequences of accounting scandals in the World and Turkey were mentioned. The research was conducted on independent accountants and certified public accountants (CPAs) residing in Yalova province by using the survey methodology. It was found that, insufficient audit in organizations was leading to accounting errors and fraud (Aslan, Kızıl and Din, 2017).

Adal1 and Kizll's (2017) study titled "A Research on the Responbility of Accounting Professionals to Determine and Prevent Accounting Errors and Frauds: Edirne Sample" included a questionnaire that was distributed to 36 accounting professionals residing in Edirne city of Turkey. Research data were analyzed by the SPSS package program. Study revealed several important results and one of them was especially eye-catching. Most significant and effective tool to prevent errors and fraud was indicated as external audit, but internal audit and internal control were valued as well by the accounting professionals (Adalı and Kızıl, 2017).

In Fido's study (2016) titled "Finansal Tablolarda Hile Denetimi ve Hileyi Önlemeye Yönelik Denetim Teknikleri: Türkiye ve AB Uygulamalarının Karşılaştırılması", the most effective techniques and methods were examined both in the prevention of errors and in the examination of fraud. Also, importance of auditing, the concepts of fraud and the most appropriate methods as well as techniques for detecting fraud were described. According to the research, fraud is one of the biggest problems in the face of corporations which prevent them to achieve their aims. Thus, it is essential to minimize errors occuring in financial statements. This case can only be possible by creating a suitable environment and shaping a corporate culture against fraud. Using proactive methods, following the laws and regulations, adopting accountability, setting up internal control systems and creating a zero tolerance corruption culture are all important (Fido, 2016).

K1z1l, Akman and Korkmaz's research (2015) titled "Marmara Bölgesinde Muhasebe-Denetim Mesleğinin Önemi Üzerine Bir Araştırma" discussed the importance of accounting and auditing professions in Marmara region of Turkey. It was pointed out that, the significance of accounting and auditing in the World as well as Turkey was now more evident. The reason was that, both accounting and auditing were providing several advantages to a wide range of stakeholders. Private and public sector audit practices were investigated together in this study (Kız1l, Akman and Korkmaz, 2015).

Demir's study (2014) titled "Benford Yasası ve Hile Denetiminde Kullanılması", investigated the concept and elements of audit as well as fraud. Furthermore, the Benford's Law as one of the types of controls that can avoid fraud was examined. According to the study, businesses should constitute internal control systems that can prevent fraud and create communication networks which enable employees to report to required positions about fraud incidents when they suspect. Also, fraud control units should be created to prevent fraud and errors. Moreover, firms should provide environments where these units can work effectively. Plus, numerical analysis by using Benford's Law is a useful tool for determining the probability of fraud because of its detection properties. Thus, the use of other auditing techniques by the auditor with information obtained using Benford's Law method will help to find out fraudulent transactions (Demir, 2014).

Kostova's study (2013) titled "Audit Procedures for Disclosure of Errors and Fraud in Financial Statements of Bulgarian Companies"' stated the factors that confirm the formation of frauds and errors in financial stataements as well as procedures applied in audit. Also, audit techniques are defined to detect fraud and errors at various audit phases. Based on this research, the auditing profession is not solely a job of meeting the demands of individual clients or employers. The auditor's role in error and fraud disclosure is not only related to compliance with ethical principles, but it is also tied to high professionalism evinced in response to changes in the economic environment that entities operate. Auditing procedures should aim to identify misstatements and fraudulent factors. Auditing procedures should also initiate appropriate actions to reduce audit risk. However, autitors should apply the proper techniques to respond to internal and external factors creating errors as well as frauds (Kostova, 2012).

Kandemir and Kandemir's study (2012) titled "Muhasebe Hilelerinin Önlenmesi ve Ortaya Çıkarılmasında Kullanılan Geleneksel Araç ve Yöntemler" explained how traditional tools and methods can be used more effectively to prevent and detect accounting frauds. In line with this study, various problems specific to the accounting-audit sector exist, 
which limit the effective functioning of such mechanisms. Both factors require the continuous development and update of traditional mechanisms. In view of the inability of independent auditors to reveal errors and fraud with traditional tools, it is clearly observed that proper coordination and teamwork among the professionals for the discovery of errors and frauds are a must. These professionals should not work as competitors against each other. They should complement each other for the prevention and detection of frauds (Kandemir and Kandemir, 2012).

Concerning Oyinlola's research (2010) titled "The Role of Auditors in Fraud Detection, Prevention and Reporting in Nigeria", the role of auditors is examined in fraud detection, prevention and reporting. Also, extent of the related auditing procedures is investigated. Based on this study, there is a great expectation towards auditors' duties on fraud prevention and detection. The perception is in contrast to the primary purpose of audit as projected in Intenational Standard on Auditing (ISA) 200, which only requires inspectors' comments on the financial statement, but not the company's fraud prevention and detection efforts (Oyinlola, 2010).

In regards to Kandemir's paper (2010) titled "Muhasebe Hilelerinin Ortaya Çıkarılmasında ve Önlenmesinde Bağımsız Denetimin Rolü ve Bağımsız Denetçinin Sorumluluğu", research was conducted to determine whether independent auditors are involved in the discovery and prevention of accounting frauds within the framework of individual liabilities or joint liability. Also, this study tried to reveal which institutions were responsible for accounting scandals, and how they appreciated their share of responsibility. According to the author, the contribution of all components in the control environment and financial reporting process as well as the ability of independent audit firms to increase the success and efficiency level are significant (Kandemir, 2010).

Ata, Uğurlu and Altun's article (2009) titled "Finansal Tablo Hilelerinin Önlenmesinde Denetçi Algilamalar1" investigated the potential impact of auditors' demographics on fraud risk indicators. Research also tried to identify the most significant fraud risk indicators for audit sample groups. Additionally, auditor perceptions of risk factors were compared that could assist auditors in the prevention of fraudulent financial statements, taking into account the auditors' sociodemographic characteristics. Based on the analysis of authors, pressure factor of management had emerged as the most effective factor for both sample groups. This result reveals the importance of relationship between board of directors and the audit committee. Also, the factor of management's inability to demonstrate the correct approach to internal controls is shown up as one of the most significant fraud risk indicators based on first sample group. Also, the factor of difficulties in implementing organizational control was perceived as one of the most important risk indicators (Ata, Uğurlu and Altun, 2009).

Erol's manuscript (2008) titled "İşletmelerde Yaşanan Yolsuzluklara (Hata ve Hileler) Karş1 Denetimden Beklentiler", focused on the corruption issue and risk factors leading to corruption. Also, expectations from the audit operations were investigated. According to the author, most of the corruption experienced in business stem from the preparation or concealment of incomplete or fraudulent financial reporting. Additionally, the procedure to struggle with corruption is to implement corporate governance effectively and perform the requirements of auditing. Moreover, in order to secure the financial reporting process, there is a need for honest managers, auditors equipped with sufficient information and users with sufficient skills (Erol, 2008).

\section{Case Analysis}

Olympus, Worldcom, Tesco, Sunbeam and Parmalat companies are examined as part of the case analysis and the events leading to these scandals are analzyed. These are some of the leading accounting scandals in the World. Thus, they were selected to be included in the study.

Olympus corporation was established by Takeshi Yamashita on October 1919 in Tokyo, Japan. Olympus is a Japanese firm that produces medical imaging equipment and cameras. In 2011, a big accounting scandal came to light in Olympus company. Announcement of the job termination of company's former CEO, Woodford led to the outbreak of Olympus scandal. After being fired, Woodford made a statement to the press that Olympus forced him to resign from his job because he interrogated the payment of $\$ 687$ million in consulting fees for 2008, when British medical equipment maker Gyrus purchased $\$ 2$ billion. It was found that, Japanese Olympus had hidden its losses for many years. An independent committee was set up to examine the company's accounting operations. In an examination of the delegation established to examine the company's accounting processes, it was determined that the company with a 92-year history had used funds and other measures for purchases to postpone the loss-related records. In order to hide the losses, Olympus paid 73,4 billion yen ( $\$ 948$ million) for the purchase of three Japanese companies Altis, News Chef and Humalabo between 2006 and 2008. It was reported that, Olympus had lost 76 percent of its purchase price in March 2009 ( 55,7 billion yen ) from these three companies. Olympus company preliminarily could hide these losses by registering their assets between historic cost and fair market value. When accounting arrangements changed, management of the company forced them to book its assets at fair market value. Ultimately, the company created off-balance sheet assets to hide these losses. Olympus company purchased Gyrus and recorded investment losses as goodwill to complete this plan. Consequently, Olympus company was ordered to pay 700 million yen in fines for its role. Also, the accounting scandal hit the company's shareholders because company lost almost $80 \%$ of its value. Mr Kikukawa who was a former assistant general manager and the former auditing officer Mr Yamada were arrested. This scandal now has a place in the Japanese history as one of the biggest financial frauds (Norris, 2011).

Worldcom company was founded in 1983 by Bernard Ebbers. In a short time, the market value of the company grew to 180 billion dollars in 1990 . Worldcom was the second largest U.S. phone company in 1999. A big accounting scandal showed up in Worldcom company in 2002. Scott Sullivan who had been the chief financial officer of the corporation was fired after discovering transfers from operating expenses amounting 
to $\$ 3,8$ billion in the 5 th quarter of January 2001 - March 2002. WorldCom announced that, the profit figures for the last 15 months were to be recounted and announced, after the previous announcement indicating that the company had made a profit of $\$ 1,4$ billion in 2001. The company reported that, a total of $\$ 3,8$ billion in corporate expenses was shown as inadvertently capital investment in 2001 and in the first quarter of 2002. The Worldcom's auditing company was Arthur Andersen. Arthur Andersen realized that, there was maximum risk on Worldcom. In spite of all this, Arthur Andersen stated that, all accounts were examined and that there were no irregularities. In 1999, when the company was at peak, the stock price was over $\$ 64$. However, after the scandal in 2002, the stocks of firm declined by $9 \%$ and the company went bankrupt (The Guardian, 2002).

Tesco company as one the largest supermarket chains of United Kingdom (UK) was established by Jack Cohen in East of London in 1919. A big accounting scandal showed up in Tesco company in 2014. Financial Conduct Authority (FCA), which is a institution that regulates and monitors the capital markets in the UK investigated Tesco company on the grounds of its irregularities in accounting records. As a result of the examination, it was determined that the company overstated its profits in the first half of 2014 by $£ 263$ million. Tesco company asked Deloitte to run a comprehensive and independent audit. Deloitte completed its audit and examination. It was detected that, in the first half of 2014 the firm's profits were overrated by $£ 118$ million. This figure was $£ 70$ million in the 2013 . In 2014 financial year, this figure was $£ 75$ million. As a result, Tesco company had to pay the penalty of $£ 129$ million for this accounting scandal and also had to pay $£ 85$ million for a plan to compensate investors. The company's market value decreased significantly because of the mentioned scandal (Chapman, 2020).

Another case involves the extensive manipulation of financial statements of Sunbeam Company, which was headquartered in Florida, U.S. This manipulation had two important sources: First was the inconsistent determination of income and the other was creation of funds. The mentioned funds were created to be spent on restructuring after the change in management, but these funds were very overrated. In following periods, operating expenses were not implemented to ordinary income of the current period, but they were instead deducted from the mentioned funds. Thus, it was ensured that the income figure would not decrease. Another trouble corcerning the determination of income was that, goods that had not been actually sold were shown as sold and invoiced. Thus, the sales income was increased. As of the end of 1997, Sunbeam company recorded a revenue by $\$ 189$ million in its financial statements. However, \$62 million dollar of this figure was due to fraudulent transactions. These fraudulent figures, created by the company's general manager and senior finance manager, caused the company's share price to rise from US $\$ 12$ to US $\$ 52$ in the period of 1996-1998. It was stated that, Sunbeam firm's auditor requested only a $16 \%$ correction in the figures related to income from company management through the controls of 1997. This is because, the firm's auditor analyzed problematic transactions staying out of $16 \%$, but he did not qualify them as significant. Therefore, it was understood that the auditor did not reflect these fraudulent figures which significantly affected the owners of shares in terms of share prices. In other words, while the auditor needed to organize a negative audit report considering the total misstatement of $32,8 \%$, the auditor described only $16 \%$ of the false pretence as problematic and accordingly prepared a positive audit report (Hilzenrath, 2001).

Parmalat Company was established in 1961 by Calisto Tanzi as a milk pasteurization centre in ParmaItaly. In 1990, the company registered for Milan capital markets and it grew to be Italy's 8th largest company in a short time. At the end of 2003, $\$ 8$ billion deficit came to the foreground due to irregularities in the accounting records and it became one of the greatest scandals of Italy's history. The reason for the bankruptcy of company was shown as the exhaustion of financial resources between the year 1990 which company went to public and the year 2003 when banktruptcy occured. Financial resources were transferred to offshore and special purpose institutions in foreign countries through the banks. The scandal came into being when Bank of America rejected the $€ 500$ million bond payment. Despite the fact that there was $€ 4,2$ billion in cash on the company's balance sheet, the company had caused suspicion. The reason is that, the company had paid $€ 150$ million for current maturity with bank and government loans. As a result of the examinations initiated on this basis, it was understood that, approximately $€ 4$ billion of the money was in the accounts of Bonlet Finance Company which was a subsidiary of Parmalat Company. Bonlet Finance Company was located in Cayman Islands. However, it was seen that there was no such money and the company accounts were inflated by $€ 8$ billion. That was related with the participation of Bonlet Finance Company located in Cayman Islands. On this occasion, it was determined by the Italian prosecutors that, during 15 years there were always irregularities on accounts. The most important factor that sets the ground for the Parmalat scandal was the inadequacies observed in the independent audit of the company. Grant Thornton and Deloitte Touche were accused of not detecting the fraud in Parmalat (Jucca and Stempel, 2007).

\section{Conclusion and Recommendations}

Fraud audit gains importance every day because of increasing accounting scandals. Accounting scandals in businesses have caused significant losses both in the World and Turkey. They have macro and micro impacts. Although fraud prevention is difficult, an audit based on standards and codes of ethics can enable to reduce fraud and help for timely detection. Thus, corporations should first take their financial statements under control. For this, corporations need reliable financial statements and a powerful cost accounting system, that is used in all parts of the management function from planning to control of production activities. The information contained in financial statements prepared by the business must be delivered to interested parties in a timely, accurate, reliable, understandable, complete and up-to-date manner. Independent auditors are needed to provide this tremendous target and to increase investor confidence in financial information.

In addition, the independent auditors who audit the companies must be brought to the intended level by 
providing adequate training before and after the tasks. The reason is that, the independent auditing sector has a crucial role in ensuring the trusting environment in financial markets. Independent auditing sector is also critically important for transparency. Many different auditing techniques can be used in fraud audits. When a symptom on the presence of fraud shows up, the subject should be examined in detail with additional audit techniques. The essential element to be able to detect the fraud is that, the auditor should move in professional skepticism. In this process, inventory counting such as cash and stock can be done, the audit techniques applied can be changed, interviews with employees and management can be made and verification can be run. Also, establishing strong internal controls and benefiting from technology integrated auditing will definitely help. When a fraud is detected, it should be reported to the appropriate administrative level and related parties should face penalties. Also, solutions and recommendations should be submitted to the management of corporations in this process. The business management should establish a necessary control System as well.

Finally, fraud is a very powerful concept since it can be observed in many formats. Because of this situation, techniques to prevent fraud are as important as running audits. Internal and external auditors have big roles in detecting, preventing and reporting fraud. These are all also valid for manufacturing firms, which are involved in cost accounting practices.

\section{References}

Adal1, S., Kizıl, C. (2017). "A Research on the Responbility of Accounting Professionals to Determine and Prevent Accounting Errors and Frauds: Edirne Sample", Emerging Markets Journal (EMAJ), University of Pittsburgh Press (USA), Vol. 7, No: 1, ISSN: 2158-8708 (online), http://dx.doi.org/10.5195/emaj.2017.1 $29,53-64$.

Akdoğan, N. (2014). Maliyet Muhasebesi, Anadolu Üniversitesi, Eskişehir (Haziran 2014), 10-11.

Aslan, T., Kızıl, C. (2019). Üretim Maliyetlerinin Denetimine Genel Bir Bakış, İktisadi Yenilik Dergisi, Cilt: 6, Say1: 1, Ocak 2019, 112. http://dergipark.gov.tr/download/articlefile/616547

Aslan, T., Kızıl, C., Din, A. (2017). "Muhasebe Hata ve Hileleri Üzerinde Etkili Faktörlerin Muhasebe Meslek Etiği Kapsamında Analizi: Yalova Örneği", Journal of Social and Humanities Sciences Research (JSHSR), Cilt: 4, Sayı: 12, ISSN: 24591149, http://dx.doi.org/10.26450/jshsr.191, $1125-1138$.

Ata, H. A., Uğurlu, M., Altun, M. Ö. (2009). Finansal Tablo Hilelerinin Önlenmesinde Denetçi Algılamaları, Gaziantep Üniversitesi Sosyal Bilimler Dergisi, No: 8, Sayı: 1, 215-230.
Chapman, B. (2020). Watchdog Closes Five-Year Probe into Tesco's $£ 250 \mathrm{~m}$ Accounting Scandal, Independent, https://www.independent.co.uk/news/busi ness/news/watchdog-closes-tescoaccounting-scandal-investigationa9554296.html (Accessed: 22.05.2020).

Demir, M. (2014). Benford Yasası ve Hile Denetiminde Kullanılması, Yayınlanmamış Yüksek Lisans Tezi. İstanbul Ticaret Üniversitesi Sosyal Bilimler Enstitüsü, İstanbul.

Emir, M. (2008). Hile Denetimi, Mali Çözüm Dergisi, No: 86., Mart-Nisan 2008, 110.

Erol, M. (2008). İşletmelerde Yaşanan Yolsuzluklara (Hata ve Hileler) Karșı Denetimden Beklentiler, Süleyman Demirel Üniversitesi, İ̈BF Dergisi, Cilt: 13, Say1: 1, 229-237.

Fido, E. M. (2016). Finansal Tablolarda Hile Denetimi ve Hileyi Önlemeye Yönelik Denetim Teknikleri: Türkiye ve AB Uygulamalarının Karşılaştırılması, Yüksek Lisans Tezi, Selçuk Üniversitesi Sosyal Bilimleri Enstitüsü, Konya.

Güredin, E. (1999). Denetim, Beta Basım Yayım Dağıtım A.Ş., İstanbul.

Hilzenrath, D. S. (2001). Sunbeam Accussed of Fraud, The Washington Post, https://www.washingtonpost.com/archive/busi ness/2001/05/16/sunbeam-accused-offraud/4e03a2b8-c4da-4a00-bea8f0cb55cb8d77/ (Accessed on: 24.05.2020).

Jucca, L., Stempel, J. (2007). UPDATE 3-Deloitte to Pay Parmalat \$149 Mln to Settle Suit, The Reuters Web https://www.reuters.com/article/parmalatdeloitte-agreement-idUSL124205520070112 (Accessed on: 25.05.2020).

Kandemir, C. (2010). Muhasebe Hilelerinin Ortaya Çıkarılmasında ve Önlenmesinde Bağımsız Denetimin Rolü ve Bağımsız Denetçinin Sorumluluğu, Doktora Tezi, Çukurova Üniversitesi Sosyal Bilimler Enstitüsü, Adana.

Kandemir, C., Kandemir, Ș. (2012). Muhasebe Hilelerini Önlemede Çözüm Yolu Olarak Kullanılacak Stratejilerin Bileşenleri, Mali Çözüm Dergisi, No: 111, May1s-Haziran 2012, 15-42.

Kandemir, C., Kandemir, Ş. (2012). 'Muhasebe Hilelerinin Önlenmesi ve Ortaya Çıkarılmasında Kullanılan Geleneksel Araç ve Yöntemler, Mali Çözüm Dergisi, No:113, Eylül-Ekim 2012, 39-74. 
Kızıl, A., Kızıl C. (2007). Accounting: Financial, Cost, Managerial. Bahar Yayınevi, İstanbul, Türkiye, ISBN: 994463070-5.

Kızıl, C., Akman, V., Korkmaz, H. (2015). "Marmara Bölgesinde Muhasebe-Denetim Mesleğinin Önemi Üzerine Bir Araştırma", Akademik Sosyal Araştırmalar Dergisi (ASOS Journal), Y1l: 3, Say1: 10, Mart 2015, 193211.http://www.asosjournal.com/Makaleler/75 4101230_510\%20Cevdet\%20 KIZIL.pdf

Kızıl, C., Doğan, E. (2017). Audit Techniques for Protecting against Cyber Attacks: A Bilateral Approach of Case Studies and Interview in Societal Complexity, Data Mining and Gaming; State-of-the-Art 2017, Dorien DeTombe, Gerhard-Wilhelm Weber and Semih Kuter (Eds.), Amsterdam Europe: Greenhill \& Waterfront. Versiyon: 001, Amsterdam, Hollanda, ISBN /EAN: 978-90-77171-54-7. 125-135.

Kızıl, C. et. al. (2019). İktisadi ve Sosyal Yönleriyle İnovasyon kitabı içerisinde Bölüm 5: İnovasyonun Muhasebe ve Denetime Etkileri kitap bölüm yazarlığı. Editörler: Birgül Uyan ve Musa Çakır, IKSAD Yayınevi (IKSAD Publications), Temmuz 2019, Ankara, Türkiye, ISBN: $\quad$ 978-605-7695-031. https://www.iksad.net/product-page/iktisadive-sosyal-y\%C3\%B6nleriyle-inovasyon

Kızıl, C., Kaşbaşı, B. (2018). Accounting Scandals and Eye-Catching Frauds: USA-Japan Comparison by Considering the Role of Auditing, Journal of Asian Research (JAR), ISSN: 2575-1581 (online), Vol. 2, No: 3, ss.123138, http://dx.doi.org/10.22158/jar.v2n3p123

Kostova, S. (2012). Audit Procedures for Disclosure of Errors and Fraud in Financial Statements of Bulgarian Companies, Faculty of Economic Accounting D.A. Tsenov Academy of Economics, Svishtov, Bulgaria (July), 49-66.

Norris, F. (2011). Deep Roots of Fraud at Olympus, The New York Times, https://www.nytimes.com/2011/12/09/business /deep-roots-of-fraud-at-olympus.html (Accessed: 20.05.2020).

Omair, B., Alturki, A. (2020). Systematic Literature Review of Fraud Detection Metrics in Business Processes, IEEE Access, DOI: 10.1109/ACCESS.2020.2971604 https://ieeexplore.ieee.org/stamp/stamp.jsp?arn umber $=8981992$

Oyinlola, A. O. Mr. (2010). The Role Of Auditors in Fraud Detection, Prevention and Reporting in Nigeria, Library Philosophy and Practice, 517.

Özay, T. (1992). Yönetimde Muhasebenin Yeri, Mali Çözüm Dergisi, No: 12, Şubat-Mart 1992.
Öztürk, V. (2016). Muhasebe, Ankara Kariyer Yayınları, 3. Bask1, Ankara.

Şakrak, M. (1997). Maliyet Yönetimi, Yasa Yayınları, İstanbul.

The Guardian. (2002). WorldCom Accounting Scandal. The Guardian Website. https://www.theguardian.com/business/2002/au g/09/corporatefraud.worldcom2 (Accessed: 21.05.2020). 